\title{
Rapid test to detect cytotoxic activity in vaccines against foot-and-mouth disease
}

\section{Prova rápida para detectar atividade citotóxica em vacinas para febre aftosa}

\author{
Rossana María Allende ${ }^{1 *}$ (1) (https://orcid.org/0000-0003-3330-5057) \\ Diego Fontana de Andrade 2 (1) (https://orcid.org/0000-0003-4639-3519) \\ Jose Lourenço Reis' ${ }^{1}$ (1) (https://orcid.org/0000-0002-1852-6241) \\ Edviges Maristela Pituco' (1) (https://orcid.org/0000-0003-1469-9257)
}

\begin{abstract}
Substances with cytotoxic activity present in vaccines against the foot-and-mouth disease may interfere with methods used to detect residual live virus in the product or cause undesirable postvaccination reactions. This study describes a rapid in vitro test to detect cytotoxic activity in water-in-oil vaccines against foot-and-mouth disease using a commercial saponin as a cytotoxic agent and a solution of sheep's red blood cells as substrate. Hemolytic and cytotoxic activity was analyzed using experimental and commercial vaccines prepared with and without saponin. The hemolytic and cytotoxic potential of preparations containing saponin was evident. In contrast, hemolytic and cytotoxic activities were not observed in vaccines without saponin in their composition. The method described here allows to easily detect if the vaccine under study has cytotoxic activity, making it possible to select the most appropriate method to process the sample to be used for the innocuity test. Additionally, due to undesirable effects that may be observed in animals receiving vaccines containing saponin in their formulation, the use of the rapid test described here allows to identify those vaccines with cytotoxic activity and to verify the presence of saponin on them, through the mass spectrometry method.
\end{abstract}

KEYWORDS: foot-and-mouth disease; vaccines; saponin; cytotoxicity.
RESUMO: Substâncias com atividade citotóxica presentes em vacinas contra febre aftosa podem interferir com o método utilizado para a detecção de vírus ativo residual no produto ou causar reaçóes pós-vacinais indesejáveis. O presente trabalho descreve uma prova rápida in vitro para detectar atividade citotóxica em vacinas oleosas contra febre aftosa utilizando uma saponina comercial como agente citotóxico e uma solução de hemácias de carneiro como substrato. Analisaram-se as atividades hemolítica e citotóxica utilizando-se vacinas experimentais e comerciais preparadas com e sem saponina. O potencial hemolítico e citotóxico dos preparados que continham saponina na sua formulação foi evidente. Em contraste, não se observou atividade hemolítica e citotóxica nas vacinas sem saponina. $\mathrm{O}$ método descrito permite conhecer rapidamente se a vacina em estudo apresenta atividade citotóxica e, dessa maneira, selecionar o método mais adequado para processar a amostra que será utilizada para investigar a presença de vírus ativo residual. Adicionalmente, devido aos efeitos indesejáveis que podem ser observados em animais que recebem vacinas que contêm saponina na sua formulação, o uso da prova rápida descrita permite selecionar aquelas vacinas com atividade citotóxica para posteriormente verificar a presença de saponina através de técnicas analíticas como a espectrometria de massas.

PALAVRAS-CHAVE: febre aftosa; vacinas; saponina; citotoxicidade. 


\section{INTRODUCTION}

The presence of substance with cytotoxic activity in waterin-oil vaccines against foot-and-mouth disease (FMD) may interfere with the method used for innocuity test in the final product. In addition, it can cause inflammatory reactions at the inoculation site to vaccinated animals. To confirm absence of residual live virus in the final product an innocuity test is performed. Cell cultures, mainly BHK-21 or IB-RS-II cell lines sensitive to FMD virus, are used as substrate for innocuity tests. Cytotoxic substances present in the material under study can alter the metabolism of these substrates, destroying the cells, thus reducing the sensitivity of the method to detect residual live virus. Additionally, substances with cytotoxic activity present in the composition of vaccines might induce undesirable local reaction at the site of inoculation in animals. The addition of immunomodulators in veterinary vaccines is a common practice. The substance saponin has historically been used as immunomodulator in FMD vaccines with aluminum hydroxide adjuvant (ESPINET, 1951) and in oil formulated FMD vaccines or emergency aqueous vaccines (SMITSAART et al., 2001; DARSIE et al., 1998-2001).

Saponins used in veterinary vaccines are mostly natural products extracted from the tree Quillaja saponaria Molina. Generally, they consist of heterogeneous preparations including raw extracts of Quillaja bark (CAMPBELL; PEERBAYE, 1992). Depending on its origin and extraction method, the immunomodulatory activity of saponin varies considerably, making it necessary to study each batch produced to verify its activity as adjuvant. Commercial preparations consisting of mixtures of different fractions of saponins, purified and standardized, as well as semisynthetic analogues are also available (KENSIL et al., 1991; CAMPBELL; PEERBAYE, 1992; MARCIANI et al., 2003; RAJPUT el al., 2007; CAO, 2014; ZHU; TUO, 2016).

Chemically, saponins consist of a steroid or triterpene (hydrophobic) ring to which one or more sugar chains (hydrophilic) are associated, which gives them an amphipathic nature. Due to their amphipathic nature, saponins have detergent activity, being able to produce toxicity and cell lysis (KENSIL et al., 1991; FERNÁNDEZ-TEJEDA et al., 2016). This makes that, depending on the concentration used in the vaccines, they can alter the sensitivity of tests used to detect residual live virus (innocuity) as well as to produce undesirable local reactions in animals receiving the vaccine.

This article describes a rapid in vitro test to detect cytolytic activity in supernatants eluted from water-in-oil vaccines against FMD. Considering the cytotoxic and hemolytic characteristics of saponins, experimental water-in-oil vaccines were prepared using inactivated antigens (O1Campos, A24 Cruzeiro and C3 Indaial) and different concentrations of saponin (P3 Food Ind. Limited).
The ability of the implemented methods to reveal cytotoxic and hemolytic activities on the supernatant eluted from those vaccines was analyzed. Finally, two commercial water-in-oil vaccines formulated with and without saponin, respectively, and previously analyzed by the mass spectrometry method at the FMD Vaccines Quality Control Laboratory of Federal Laboratory of Animal and Plant Health Inspection (LFDA/RS) (ANDRADE et al., 2020) were analyzed by the method described here to validate the results obtained in the rapid test.

\section{MATERIAL AND METHODS}

Water-in-oil trivalent vaccines against FMD were prepared following the PANAFTOSA method (OPS, 1987). Binary ethylenminie (BEI) inactivated antigens $\mathrm{O} 1 \mathrm{Campos} \mathrm{Br}$ 1/58, A24 Cruzeiro Br 1/55 and C3 Indaial Br 1/72 were included. The total volume of trivalent antigen was divided into subvolumes to which saponin P3 (Food Ind. Limited) was added in concentrations of 1.0, 1.5, 2.0 and $3.0 \mathrm{mg} / \mathrm{mL}$, respectively. Subsequently, oil adjuvant was added, preparing water-in-oil type emulsions. Each vaccine dose was of $5 \mathrm{~mL}$ and the different preparations ended with 2.5, 3.75, 5.0 and $7.5 \mathrm{mg}$, of saponin per dose, respectively. Additionally, a vaccine batch without saponin was prepared. Samples from two batches of vaccine from the same commercial brand were used for comparison with the mass spectrometry method. According to the information on the vaccine labels, the antigenic composition was the same; the only difference was that one of them contained saponin on its formulation and the other did not contain this substance.

Vaccines were treated with chloroform $(100 \mathrm{~mL}$ vaccine / $50 \mathrm{~mL}$ chloroform) and centrifuged at 2,500 rpm for $15 \mathrm{~min}$. The aqueous supernatant containing the antigen was carefully transferred into a sterile container duly identified and kept at $+4^{\circ} \mathrm{C}$ until the moment of use in tests of hemolytic and cytotoxic activity. A fraction of the eluted antigen was treated with polyethylene glycol (PEG) 6000.

A fraction of each eluate was treated with $10 \%$ PEG 6000. Mixtures were kept under stirring for $3 \mathrm{~h}$ at $+4^{\circ} \mathrm{C}$ and subsequently centrifuged at $10,000 \mathrm{rpm}$ for $10 \mathrm{~min}$. After separating the supernatant, the pellet was suspended with minimum essential medium (MEM) at $10 \%$ of the original eluted volume. The presence of the $\mathrm{O}, \mathrm{A}$ and $\mathrm{C}$ antigens in the suspended pellet was confirmed by serological test (complement fixation and/or indirect sandwich ELISA).

The in vitro method previously described by LIU et al. (2002) was used with some modifications. Samples under study were diluted in phosphate buffered saline (PBS) free of calcium and magnesium, in base 2 in 96-microwell plates with round bottom. In all cases a volume of $100 \mu \mathrm{L}$ per well was used. Then $25 \mu \mathrm{L}$ of a $2 \%$ suspension of sheep red blood cells 
in PBS free of calcium and magnesium was added to each well. Distilled water and PBS were used as controls in separate wells for 100 and $0 \%$ hemolysis, respectively. Microplate were incubated during $30 \mathrm{~min}$ at $22-25^{\circ} \mathrm{C}$. The reading was done in a microcolor test mirror, recording the highest dilution of each sample where hemolysis was observed. The same experiment was performed in tubes, using volumes of $1 \mathrm{~mL}$ and $0.25 \mathrm{~mL}$ for the sample and red blood cells suspension, respectively. Once the incubation was completed, the tubes were centrifuged and the absorbance read in a spectrophotometer with a $545 \mathrm{~nm}$ filter.

Falcon type and roller bottles with BHK-21 cell monolayers were used in the experiment. After removing the growth medium, a sample of each vaccine eluate was inoculated onto cell monolayers. Bottles were incubated at $37^{\circ} \mathrm{C}$ over a period of $20 \mathrm{~min}$ to allow adsorption of the antigen. Subsequently, the corresponding volume of maintenance medium was added and bottles were returned to the incubator chamber. Cell monolayers were observed over a period of $48 \mathrm{~h}$ and then frozen and thawed for a second passage. A total of three passages were made with each sample.

The method described by ANDRADE et al., (2020) and in routine use at the FMD Vaccines Quality Control Laboratory of LFDA/RS was applied. The method is a qualitative analysis of FMD vaccine samples through the combination of liquid chromatography and high-resolution mass spectrometry techniques to verify the presence or absence of saponins derived from extracts of $Q$. saponaria tree bark.

\section{RESULTS}

Table 1 summarizes the results obtained. Distilled water and PBS were used as controls in separate columns for 100 and $0 \%$ hemolysis, respectively. A visible sediment of red blood cells at the microwell bottom, similar to that of the $0 \%$ hemolysis control indicates absence of hemolytic activity in the sample under analysis. Decreasing sediment size or its absence indicates the presence of hemolytic activity. Eluates from vaccine without saponin showed hemolytic activity at dilutions lower than 1:2.
Vaccine eluates containing saponin showed hemolytic activity at dilutions varying from 1:5 to $>1: 32$, and they were directly related to the concentration of saponin in the original product. Supernatants of materials treated with PEG 6000, conserved their hemolytic activity while sediments suspended in MEM did not shown hemolytic activity. No difference was observed between the result of the tests in microplate (visual reading) and in tubes (spectrophotometric reading). Saponin concentrations producing hemolysis at a 1:4 dilution, showed toxicity (cell death) on substrates inoculated with adsorption period. It was possible to observe this effect within 2-5 h after inoculation. When inoculation was performed without adsorption (cells covered with maintenance medium), a toxic effect (cell death) was observed in those substrates in which the inoculum presented hemolysis in dilutions greater than 1:10 (Table 1).

Cytotoxic effect was also observed in supernatants from mixtures treated with PEG 6000, but not in their sediments resuspended in MEM. The mass spectrometry study showed the absence of saponin in the commercial vaccine without saponin and the presence of this substance in the commercial vaccine identified as with saponin (data not shown). Figure 1 and Table 2 show the results obtained with the commercial vaccine formulated without saponin. Distilled water and PBS were used as controls in separate columns for 100 and $0 \%$ hemolysis, respectively. The visible presence of a sediment of red blood cells at the bottom of the well similar to that observed at the $0 \%$ hemolysis control indicates absence of hemolytic activity in the sample under analysis. The decrease in the sediment size or its absence indicates the presence of hemolytic activity. Vaccine formulated without saponin presented hemolytic activity at dilutions lower than 1:2 in any of the three samples (full eluate, supernatant post-treatment with PEG, and resuspended pellet).

Results obtained with the commercial vaccine formulated containing saponin are depicted in Figure 2 and Table 3. Hemolytic activity was observed up to 1:16 dilution of the entire eluate and of the supernatant after treatment with PEG. In the pellet after treatment with PEG and resuspended in MEM, hemolytic activity was observed in dilutions lower than 1:2. In the two vaccines analyzed, there was agreement between results of the microplate test (visual reading) and tube test (spectrophotometric reading).

Table 1. Results of hemolytic and cytotoxic activities of vaccine samples prepared with different saponin concentrations.

\begin{tabular}{|c|c|c|c|c|c|}
\hline \multirow{2}{*}{ mg saponin/mL vaccine } & \multicolumn{2}{|c|}{ Hemolytic activity } & \multicolumn{3}{|c|}{ Cytotoxic activity on BHK-21 cell line } \\
\hline & Eluate & PEG $^{1}$ & With Adsorption ${ }^{3}$ & W/o Adsorption ${ }^{3}$ & PEG ${ }^{1}$ \\
\hline $0.00 \mathrm{mg} / \mathrm{mL}$ & $<1: 2^{2}$ & No & No & No & No \\
\hline $0.50 \mathrm{mg} / \mathrm{mL}$ & $1: 24$ & No & $100 \%$ & No & No \\
\hline $0.75 \mathrm{mg} / \mathrm{mL}$ & $1: 30$ & No & $100 \%$ & $10 \%$ & No \\
\hline $1.00 \mathrm{mg} / \mathrm{mL}$ & $1: 40$ & No & $100 \%$ & $20 \%$ & No \\
\hline $1.25 \mathrm{mg} / \mathrm{mL}$ & $1: 60$ & No & $100 \%$ & $80 \%$ & No \\
\hline
\end{tabular}

'Eluate treated with PEG and re-suspended in MEM. ${ }^{2}$ Higher dilution where hemolysis was observed. ${ }^{3}$ The inoculum used was the vaccine eluate. 


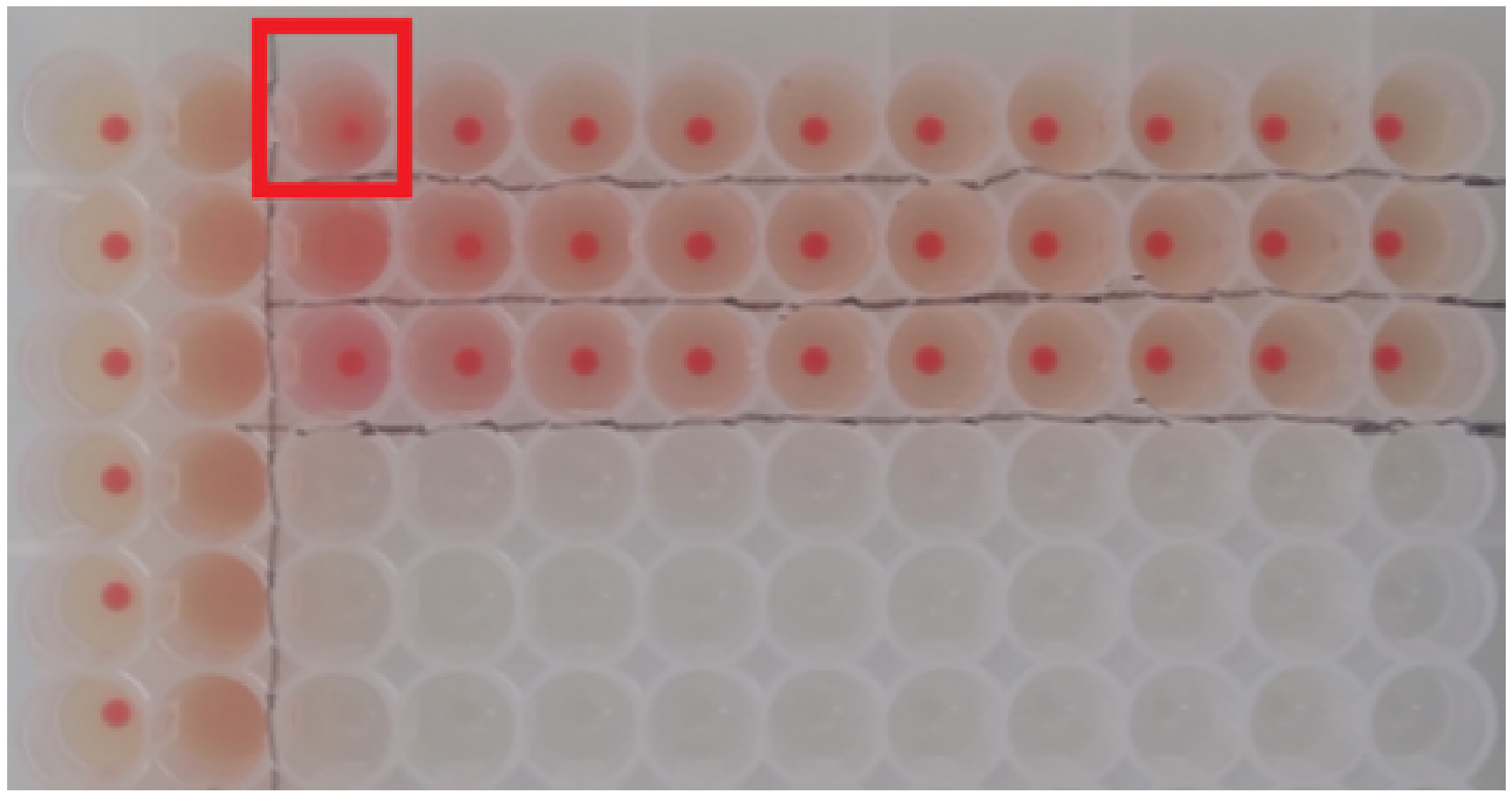

Figure 1. Layout of round-bottom microplate for the evaluation of hemolytic activity of vaccine sample without saponin. Red square shows the highest dilution with visible reduction of red blood cells sediment (1:1).

Table 2. Schema of controls and sample dilutions positions in the round bottom microplate to evaluate hemolytic activity in commercial vaccine without saponin.

\begin{tabular}{|c|c|c|c|c|c|c|c|c|c|c|c|}
\hline $\mathrm{CN}$ & $\mathrm{CP}$ & E 1:1 & E 1:2 & E $1: 4$ & E 1:8 & E 1:16 & E 1:32 & E 1:64 & E $1: 128$ & E 1:256 & E 1:512 \\
\hline $\mathrm{CN}$ & $\mathrm{CP}$ & S 1:1 & S 1:2 & S $1: 4$ & S 1:8 & S $1: 16$ & S 1:32 & S 1:64 & S $1: 128$ & S 1:256 & S 1:512 \\
\hline $\mathrm{CN}$ & $\mathrm{CP}$ & R $1: 1$ & R $1: 2$ & R $1: 4$ & R 1:8 & R $1: 16$ & R 1:32 & R 1:64 & R $1: 128$ & R 1:256 & R 1:512 \\
\hline $\mathrm{CN}$ & $\mathrm{CP}$ & & & & & & & & & & \\
\hline $\mathrm{CN}$ & $\mathrm{CP}$ & & & & & & & & & & \\
\hline $\mathrm{CN}$ & CP & & & & & & & & & & \\
\hline
\end{tabular}

CN: PBS Control (O\% hemolysis); CP: distilled water control (100\% hemolysis); E: eluate; S: supernatant; R: resuspended sediment.

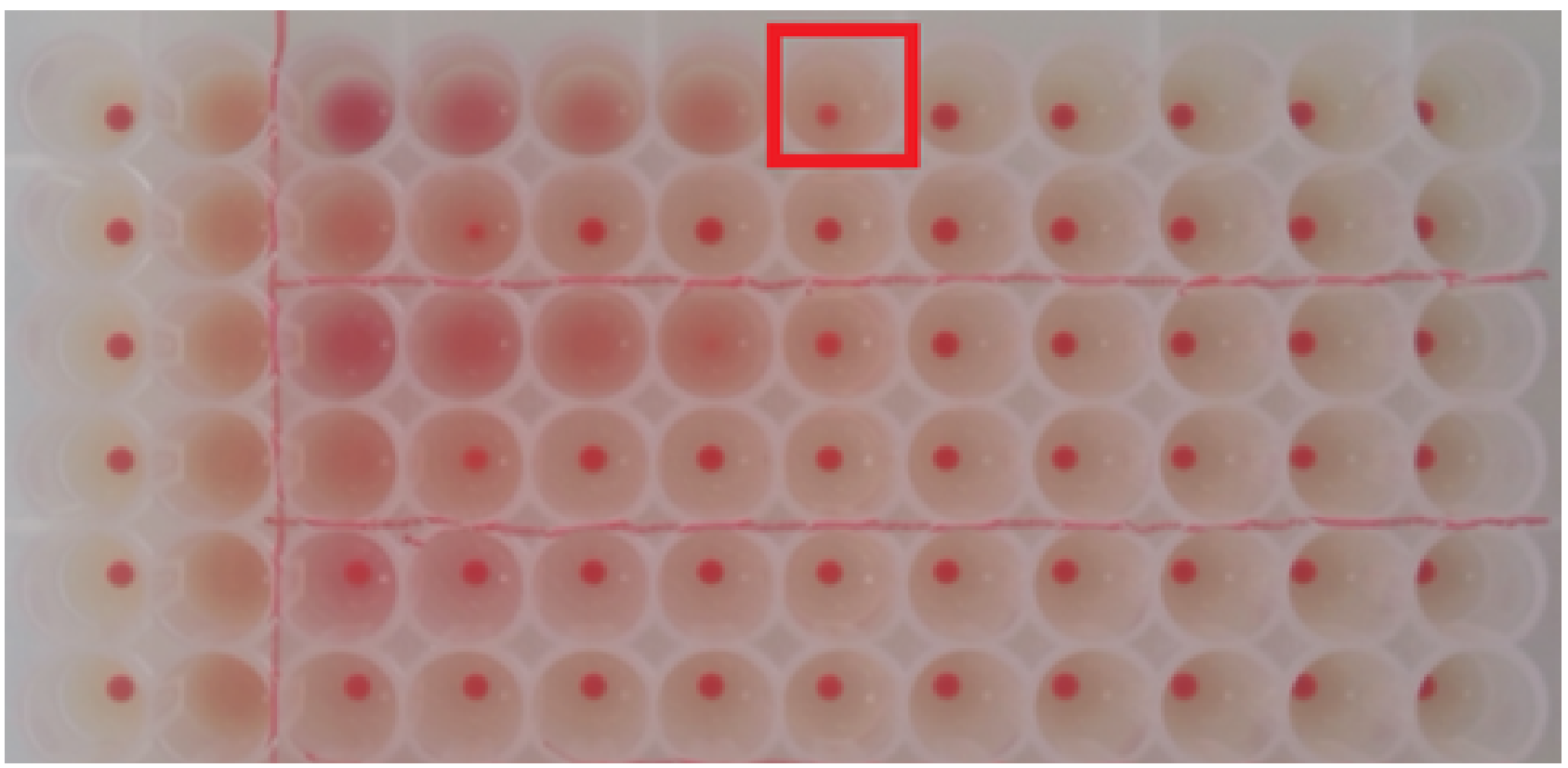

Figure 2. Layout of round-bottom microplate for the evaluation of hemolytic activity of vaccine sample with saponin. Red square shows the highest dilution with visible reduction of red blood cells sediment (1:16). 
Table 3. Schema of controls and sample dilutions positions in the round bottom microplate to evaluate hemolytic activity in commercial vaccine with saponin

\begin{tabular}{|c|c|c|c|c|c|c|c|c|c|c|c|}
\hline $\mathrm{CN}$ & $\mathrm{CP}$ & E $1: 1$ & E $1: 2$ & E 1:4 & E 1:8 & E 1:16 & E 1:32 & E 1:64 & E 1:128 & E 1:256 & E 1:512 \\
\hline $\mathrm{CN}$ & $\mathrm{CP}$ & E 1:5 & E 1:10 & E 1:20 & E 1:40 & E 1:80 & E 1:160 & E 1:320 & E 1:640 & E 1:1280 & E 1:2560 \\
\hline $\mathrm{CN}$ & $\mathrm{CP}$ & $\mathrm{S} 1: 1$ & S $1: 2$ & S $1: 4$ & S 1:8 & S $1: 16$ & S 1:32 & S 1:64 & S $1: 128$ & S $1: 256$ & S 1:512 \\
\hline $\mathrm{CN}$ & $\mathrm{CP}$ & S $1: 5$ & S $1: 10$ & S 1:20 & S $1: 40$ & S 1:80 & S $1: 160$ & S $1: 320$ & S $1: 640$ & S 1:1280 & S $1: 2560$ \\
\hline $\mathrm{CN}$ & $\mathrm{CP}$ & R $1: 1$ & R $1: 2$ & R $1: 4$ & R 1:8 & R $1: 16$ & R $1: 32$ & R 1:64 & R $1: 128$ & R 1:256 & R 1:512 \\
\hline $\mathrm{CN}$ & $\mathrm{CP}$ & R $1: 5$ & R $1: 10$ & R 1:20 & R $1: 40$ & R 1:80 & R $1: 160$ & R 1:320 & R 1:640 & R 1:1280 & R 1:2560 \\
\hline
\end{tabular}

CN: PBS Control (O\% hemolysis); CP: distilled water control (100\% hemolysis); E: eluate; S: supernatant; R: resuspended sediment.

\section{DISCUSSION}

The present work describes a simple methodology whose preliminary results at experimental level suggest that it can be applied to detect the presence of cytotoxic substances in vaccines against FMD. The presence of cytotoxic substances in FMD vaccines in a sufficient concentration to induce cell death is a critical factor affecting the sensitivity of methods used to identify residual active virus. Additionally, the presence of these substances in vaccines can induce undesirable reactions in animals receiving the vaccines.

This study used experimental vaccines containing saponin as a cytotoxic substance. Depending on the quality and concentration in which the saponin is included in the formulation of FMD vaccines, it can produce a cytotoxic effect both in vitro and in vivo. In relation to hemolytic activity, an evident hemolytic potential was observed in both, the vaccine eluate and the supernatant after treatment with PEG of vaccines containing saponin in their composition. In contrast, no expressive hemolytic activity was observed in vaccines that do not contained saponin. In both cases (vaccines with and without saponin), no hemolytic activity was found in sediment fractions (after PEG treatment) resuspended. Knowing the hemolytic activity of the inoculum is possible to select the most suitable method to process the sample used to investigate residual active virus.

In conclusion the test described here is easy to perform and allows the analysis of large number of vaccine batches in a short period of time. It could be used in the vaccine quality control process as screening test to identify hemolytic activity in the product, and select the appropriate sample for innocuity test. Furthermore, due to the undesirable effects that could be observed in animals receiving vaccines containing saponin in their formulation, it is important to emphasize that positive hemolytic results obtained with the rapid test, must be confirmed by mass spectrometry method to identify the presence of saponin.

ACKNOWLEDGEMENTS: Authors are thankful to Mr. Jorge Sebastião dos Santos for his technical excellence in the execution of serological tests during the study of experimental vaccines. Authors also thank the FMD vaccines Quality Control Laboratory (CVA), the Department of Inspection of Livestock Inputs (DFIP) and the Coordination of Veterinary Products (CPV) from Brazilian Ministry of Agriculture, Livestock and Food Supply (MAPA), for material support to carry out mass spectrometry studies and serological tests with commercial vaccines.

FUNDING: Not applicable.

CONFLICTS OF INTEREST: All authors declare that they have no conflict of interest.

ETHICAL APPROVAL: Not applicable.

AVAILABILITY OF DATA AND MATERIAL: All data generated or analyzed during this study are included in this published article.

AUTHORS' CONTRIBUTIONS: Conceptualization: Allende, R.M. Data curation: Allende, R.M.; Andrade, D.F.; Pituco, E.M. Formal analysis: Allende, R.M.; Andrade, D.F. Methodology: Reis, J.L; Andrade, D.F. Supervision: Allende, R.M. Writing review \& editing: Allende, R.M.; Andrade, D.F.; Pituco, E.M.; Reis, J.L. 


\section{REFERENCES}

ANDRADE, D.F.; JANK, L.; REGO, V.B.; MINOZZO, R.; SFOGGIA, M.V.B.; BAVARESCO, Á.; BARRETO, F. A liquid chromatography coupled to quadrupole-time-of-flight-mass spectrometry (LC-QTOF-MS) method for identification analysis of saponins from Quillaja saponaria bark extracts in foot-and-mouth disease vaccines: Development, validation and applicability. Biomedical Chromatography, Athens, v.34, n.9, e4873, 2020. https://doi. org/ $10.1002 /$ bmc.4873

CAMPBELL, J.B.; PEERBAYE, Y.A. Saponin. Research in Immunology, Jackson, v.143, n.5, p.526-530, 1992. https:// doi.org/10.1016/0923-2494(92)80064-R

CAO, Y. Adjuvants for foot-and-mouth disease virus vaccines: recent progress. Expert Review of Vaccines, London, v. 13, n.1 1, p.1377-1385, 2014. https://doi.org/10.1586/14760584.2014.963562

DARSIE, G.C.; REIS, J.L.; RAMALHO, A.K. Vacinação emergencial de bovinos contra a febre aftosa. Boletin del Centro Panamericano de Fiebre Aftosa, Rio de Janeiro, v.64-67, p.26-29, 1998-2001.

ESPINET, R.G. Nouveau vaccine antiaphteux a complexe glucoviral. Gaceta Veterinaria, Argentina, v.13, p.268, 1951.

FERNÁNDEZ-TEJEDA, A.; TAN, D.S.; GIN, D.Y. Development of improved vaccine adjuvants based on the saponin natural product QS-21 through chemical synthesis. Accounts of Chemical Research, Utah, v.49, n.9, p.1741-1756, 2016. https://doi.org/10.1021/ acs.accounts.6b00242

KENSIL, C.R.; PATEL, U.; LENNICK, M.; MARCIANI, D. Separation and characterization of saponins with adjuvant activity from Quillaja saponaria Molina cortex. The Journal of Immunology, Rockville, v.146, n.2, p.431-437, 1991. Available from: https://www. jimmunol.org/content/146/2/431. Access on: 25 Jan. 2019.
LIU, G.; ANDERSON, C.; SCALTRETO, H.; BARBON, J.; KENSIL, C.R. QS-2 1 structure/function studies: effect of acylation on adjuvant activity. Vaccine, Rochester, v.20, n.21-22, p.2808-2815, 2002. https://doi.org/10.1016/ S0264-410X(02)00209-8

MARCIANI, D.J.; REYNOLDS, R.C.; PATHAK, A.K.; FINLEYWOODMAN, K.; MAY, R.D. Fractionation, structural studies and immunological characterization of the semi-synthetic Quillaja saponins derivative GPI-0100. Vaccine, Rochester, v.21, n.25-26, p.3961-3971, 2003. https://doi.org/10.1016/ S0264-410X(03)00298-6

OPS; OMS; BID. PROASA - Programa de Adiestramiento en Salud Animal para América Latina. Produccion, control de calidad y uso de vacunas con adyuvante oleoso contra la fiebre aftosa. Washington: Organización Panamericana de la Salud, 1987. 260p.

RAJPUT, Z.I.; HU, S.-H.; XIAO, C.W.; ARIJO, A.G. Adjuvant effect of saponins on animal immune response. Journal of Zhejiang University SCIENCE B, Zhejiang, v.8, n.3, p.153-161, 2007. https://doi.org/10.1631/jzus.2007.BO153

SMITSAART, E.; MATTION, N.; FILIPPI, J.L.; ROBIOLO, B.; PERIOLO, O.; LA TORRE, J.; BELLINZONI, R.C. Enhancement of the immune response induced by the inclusion of saponin in oil adjuvanted vaccines against foot-and-mouth disease. In: Session of the Research Group of the Standing Technical Committee of the European Commission for the Control of FMD. Anais... Bulgaria, 2001, p.255-262.

ZHU, D.; TUO, W. QS-21: A potent vaccine adjuvant. Natural Products Chemistry Research, Barcelona, v.3, n.4, p.e 1 13, 2015. https://doi.org/10.4172/2329-6836.1000e 113 